\title{
Evaluation of Mutual Funds Performance And Consistency test over the use of Performance Sizing Methods
}

\author{
Eka Kusumawati \\ Master of Management, Perbanas Institute \\ Jakarta, Indonesia
}

\begin{abstract}
The development of mutual fund industry in Indonesia has increases every year. From those several types of equity funds, the Net Asset Value (NAV) of mutual funds has increased by quite high number from year to year compared to other types. This research was assess the performance of mutual funds and examine those several consistency over the use of performance sizing methods from Sharpe ratio, Treynor index and Jensen's Alpha methods. Current problem who was stumbled was how the performance of stock mutual funds was measured by the Sharpe ratio, Treynor index and Jensen's Alpha methods and whether there has consistency over its performance by using it. The recent sample was 37 mutual funds that were registered at BAPEPAM-LK and still operating in Indonesia from January 2009 to October 2013. Performance evaluations used Sharpe ratio method, Treynor index and Jensen's Alpha. As for assess those consistency of the use performance sizing methods was done by Kendall coefficient of concordance $(W)$ test. The result over this research said that Panin Dana Maksima and Panin Dana Prima are the best mutual funds, this could be seen during these surveillance period which found that mutual fund has superior performance above the market. The result of consistency test over those performance of stock mutual funds using Kendall W's concordance coefficient found that there has consistency or harmony when evaluated the performance of equity funds by using Sharpe Ratio, Treynor Index and Jensen's Alpha methods during those period.
\end{abstract}

Keywords:- Mutual Funds, Performance Evaluation, Consistency.

\section{INTRODUCTION}

\section{A. Background of the Problem}

Investment is a commitment over a number of funds or other resources made at this time with purpose to gained lots of benefits in future (Tandelilin, 2010). The two elements inherent in every investment are return (risk) and risk (risk). These two elements always have direct connection, the higher investment risk, the greater chance of results obtained and conversely.

For investors who want to invest in financial investments but don't have a lot of time and expertise in calculating their investment risk, therefore you can choose mutual funds as one of their investment instruments. This is

\author{
Ega Bagja Nugraha \\ Master of Management, Gadjah Mada University \\ Yogyakarta, Indonesia
}

because mutual funds are a practical investment place for investors who do not have enough time and knowledge to manage their money directly in a particular investment instrument.

The development of the mutual fund industry in Indonesia continues to increase every year. From several types of mutual funds, the Net Asset Value (NAV) of mutual funds has increased by a fairly high number from year to year when compared to other types of mutual funds that can be seen in Table 1 below.

\begin{tabular}{|c|c|c|c|c|}
\hline Types of Mutual Funds & $\mathbf{2 0 0 9}$ & $\mathbf{2 0 1 0}$ & $\mathbf{2 0 1 1}$ & $\mathbf{2 0 1 2}$ \\
\hline Stock & $36,507.70$ & $45,628.29$ & $61,184.14$ & $69,561.02$ \\
\hline Money Market & $5,219.71$ & $7,721.83$ & $9,883.90$ & $12,348.87$ \\
\hline Mix & $13,655.32$ & $18,167.46$ & $20,876.36$ & $21,956.63$ \\
\hline Fixed Income & $17,328.64$ & $26,648.18$ & $28,930.22$ & $34,577.74$ \\
\hline Protected & $34,738.87$ & $42,064.61$ & $41,834.59$ & $40,845.63$ \\
\hline
\end{tabular}

Table 1:- The growth of Mutual Fund NAV Level

In stock of mutual funds, investment managers will allocate most of the funds that have been collected into securities in the form of shares. Furthermore, to find out regards of those mutual funds performance, there has specifications or benchmarks that become standards or benchmark points to discover those qualities or value of certain objects (Maginn, Mcleavey, Tuttle, \& Pinto, 2007). Thus through an evaluation, it will be found that the performance of mutual funds compare to the benchmark is above or below the level. In Indonesia, tool that set up as benchmark for stock mutual funds is the Composite Stock Price Index (CSPI) return. From this performance evaluation it could be found quite a lot of mutual funds that exceed the benchmark performance when viewed by based on return.

In mutual fund performance sizing generally has 2 approaches, such as measuring the level of mutual fund returns and measuring the level of risk that adjusted performance. The three types of sizing which commonly used are Sharpe, Treynor and Jensen methods (Brigham, 2005). From this three methods it could be seen if its performance of mutual fund said to be outperform or underperform on the market. This can be seen from the positive or negative difference in ratio of each mutual fund after deducting the IHSG market ratio. 
If stock mutual fund was found with outperform performance, the other question is whether the outperform condition owned by each of mutual funds would consistent from time to time. Then if the findings on stock mutual funds performance was indicate an underperform on the market, does this condition also continue to occur in stock mutual fund.

Thus knowing the consistency over performance of stock mutual funds, both outperform and underperform, makes each investor could see from broader perspective, not only knowing that the performance of a stock mutual fund is able to surpass market performance but also the continuation of its performance, whether sustainable or not. Long-term consistency over past performance is one clue to the potential of equity funds in the future.

\section{B. Research Purposes}

The target that need to be achieved through this research are:

$>$ Assess the performance of mutual funds in period of January 2009 until October 2013, which was became the subject of research which measured by the Sharpe ratio, Treynor index and Jensen's Alpha method.

$>$ Providing the best stock mutual fund information based on performance evaluation result for period of January 2009 till October 2013 by using Sharpe ratio, Treynor index and Jensen's Alpha measurement methods.

Dxamination those consistency occours of Sharpe ratio, Treynor index and Jensen's Alpha sizing methods on mutual funds performance during period January 2009 to October 2013.

\section{THEORITICAL REVIEW}

\section{A. Investation}

Investment is a number of funds that used in hope that it could earn certain benefits in future. According to Suketi in Usman and Ratnasari (2004) investment involves spending investors' funds at the present time to get a greater return in the future, although the return from an investment is not necessarily in the form of profit. In other words, the purpose by investing those funds by investors is to get profits in future.

\section{B. Mutual Fund}

According to Law Number 8 of 1995 regarding about Capital Market, mutual funds is tools that used to collect funds from publics investor to be subsequently invested in securities portfolios by investment managers. In other words mutual funds are a place for people who want to invest their funds in securities portfolios through investment managers.

\section{Stock Mutual Fund}

Stock Mutual Fund is a mutual fund that invests at least $80 \%$ of the portfolio manages into equity securities (shares). Returns were earned by stock mutual funds are generally relatively higher than other types of mutual funds. Returns could be in form of changes in stock prices (capital gains) or dividends. Beside that to providing high returns, mutual funds also have a high risk. Risks can occur due to decreasing stock prices (capital loss).

\section{Portfolio Performance Measurement}

In measuring the portfolio performance, needs relevant variables such as the level of benefits and risks. Its another stages of evaluating portfolio investors. At this stage, portfolio performance will be contrast with other portfolios through standard procedure (Husnan, 2011).

\section{E. Sharpe Ratio}

In performance sizing Methods Is based on risk premium. The risk premium is a mismatch or difference between average performance produced by mutual funds with average risk-free investment performance, which assumes the average interest rate of Bank Indonesia Certificates. In this Sharpe method, beside has positive returns of mutual fund returns should also be above the instrument risk-free rate of return. The greater value of the Sharpe ratio, the better the mutual fund performance.

\section{F. Treynor Index}

Both Treynor and Sharpe method were also a risk premium but the difference is Treynor method uses beta divider $(\beta)$ which contained relative risk fluctuations.

\section{G. Jensen's Alpha}

The Jensen method based on developing the Capital Asset Pricing Model (CAPM). And was different from Treynor's size which uses average performance for certain sub-periods, Jensen's method uses the weekly data . Jensen method Were like, if the shape is higher positive, mutual fund performance is better. Jensen measured all the methods above from market performance also appropriate risks.

\section{METHODOLOGY}

\section{A. Population and Sample}

This research population is stock mutual funds in form of collective investment contracts. The authors used a purposive sampling method with these following conditions:

$>$ The sample taken was a stock mutual fund offered in the period January 2009 to October 2013, still active today and has a Net Asset Value (NAV) published in print media.

$>$ Data on Net Asset Value (NAV) of mutual fund shares to be taken as a sample of this writing is monthly data for the year concerned.

From these requirements, there has 37 samples of mutual fund products were obtained which met the criteria. Then the data used is historical data that obtained from various sources, such as:

$>$ Monthly NAV data per unit of 37 equity mutual funds to be used as a sample in writing. NAV data per unit of participation from the period January 2009 to October 2013, so there are 2146 data which will then be processed as writing material. Source of data on NAV per monthly investment unit of 37 equity funds was 
obtained at the Mutual Fund Information Center http://aria.bapepam.go.id.

> Monthly CSPI data on the IDX which will then be used as a benchmark in calculating the performance of mutual funds. The data was taken from the same period, which is January 2009 to October 2013, so there are 58 data. IHSG data was obtained from www.yahoofinance.com.

$>$ Data of 1-month SBI interest rate, which will be used as a risk free rate in calculating the performance of mutual funds. The data was taken from the period January 2009 to October 2013. The data was obtained from the internet site www.bi.go.id which in the BI site.

\section{B. Operational Definition}

The variable on this research is stock mutual funds Performance whose sizing use the Sharpe, Treynor and Jensen methods. The steps in analyzing the performance evaluation of stock mutual funds are:

\section{Calculating the Average Monthly Mutual Fund Returns}

The average return is calculated by adding up all returns divided by the number of periods. Return on mutual funds was obtained from the NAV per unit participation for each of the investigated stock mutual funds.

\section{1) Calculating the Average Market Return}

Market return is reflected by the Composite Stock Price Index (CSPI) for mutual funds. These reflect over the stock market Performance which illustrates the movement of stock prices. Market returns used as comparison of mutual funds performance.

\section{Calculating the Average Risk-Free Asset Return}

The calculation of the average return on risk-free assets could obtained from the average level of risk-free returns, such as the average interest rate of Bank Indonesia Certificates in certain period to assess the mutual funds performance.

\section{Calculating the Standard Deviation}

Standard deviation used to measure risk, which find out how likely the return obtained deviates from the expected value (average return). Standard deviations also indicate the deviations in average return of stock funds.

\section{$>$ Mutual Fund Beta Calculation}

Beta values are calculated from regression techniques using the CAPM model. Beta for each mutual fund was calculated by regressing mutual fund return (TRP) as the dependent variable with market return (RM) as the independent variable.

\section{Evaluation and Examination Methods}

In this research the evaluation of the stock mutual funds performance by using Sharpe Ratio, Treynor Index and Jensen's Alpha in order to obtain an overview to stock funds performance compared with market performance. Furthermore, the consistency of Sharpe Ratio, Treynor Index and Jensen's Alpha measurement performance needs to be tests and conducted on the performance of mutual funds from January 2009 to October 2013 by using the Kendall's coefficient of concordance (W) test.

\section{RESULTS AND DISCUSSION}

\section{A. Mutual Funds Performance}

From the Table 2 shows that during January 2009 to October 2013 the average return on mutual funds was lower than the average market return which means that the average return on equity funds was still below the market returns during that period. This is inversely proportional to the comparison of the standard deviation values that mutual funds have with the market. The standard deviation or total risk value of stock mutual fund returns is higher than the standard deviation of market returns during this period. Thus, during January 2009 to October 2013 with an average level of stock mutual fund returns which lower than the average level of market returns, stock mutual fund returns have a higher level of total risk than the level of risk in market.

\begin{tabular}{|c|c|c|c|c|}
\hline & Minimum & Maximum & Mean & Std. Deviation \\
\hline Stock Mutual fund & $-0,1723$ & 0,4373 & 0,0214 & 0,072 \\
\hline Market (IHSG) & $-0,09$ & 0,2013 & 0,0215 & 0,059 \\
\hline
\end{tabular}

Table 2:- Descriptive Statistics of Stock Mutual Funds and IHSG

In period of January 2009 to October 2013, there has 17 return values for mutual funds that were higher than market returns and there were 20 returns for mutual funds that lower than market returns. During that period, the highest return on mutual funds was owned by BNI Berkembang mutual funds in April 2009 and the lowest return on mutual funds was owned by Millennium Danatama mutual Fund in September 2013. While during this period the market return was the lowest in August 2013, and the highest return in April 2009.

During these period it was seen annually, only in 2009 and 2013 it were seen the average value of stock mutual fund returns higher than the average market return, beside that the average value of stock mutual fund returns in 2010 , 2011 and 2012 were lower than the average market return value. Thus during the period of January 2009 to October 2013 it was seen annually, the average value of stock mutual fund returns is lower than the average market return value.

\section{$>$ Sharpe Ratio}

By using the Sharpe Ratio estimation method it could be describe that the stock mutual fund performance still below the market performance per year during these period. The Sharpe Ratio value of stock mutual fund performance was smaller than the Sharpe Ratio value on market performance. The cause of that could be traced through the Sharpe Ratio estimation formula, where the level of portfolio risk premium was divided by the level of total risk. 
With the risk premium level of the performance of mutual funds was smaller than market performance, it becomes one of factors that the performance of mutual funds was smaller aswell. Plus Added with the level of total risk from mutual funds performance was greater than market performance, making its more smallers than the other one. By comparing the Sharpe Ratio value of stock mutual fund returns which become the object on this research compared to Sharpe Ratio value of market returns, it can be seen that stock mutual funds which the object of research could be outperform or underperform.

Sharpe Ratio estimation results show that 18 equity funds that have exceel performance or outperform in 2009, only 3 equity funds in 2010, 11 equity funds in 2011, 8 mutual funds in 2012, and 12 stock mutual funds in 2013. The rank given based on the value of Sharpe Ratio. The greater the Sharpe Ratio value, the better portfolio performance is aimed. Panin Dana Maksima Portfolio ranked first in 2009 and 2010 with the highest Sharpe Ratio values of 0.6441 and 0.9013 . In 2011 the first ranking was occupied by Emco Mantap with the highest Sharpe Ratio value of 0.1847 . In 2012 the first rank was occupied by the Syailendra Equity Opportunity Fund with the highest Sharpe Ratio value of 0.4194 . Finally in 2013 the first rank was occupied by the Millennium Danatama Equity Fund with the highest Sharpe Ratio value of 0.2796 .

\section{$>$ Treynor Index}

Test results show that the average value of Treynor index of stock mutual fund performance is smaller than the value of Treynor index on the market or CSPI in 2010 to 2013, except in 2009 the average value of Treynor index on stock mutual fund performance is greater than the value of Treynor market index. The cause of the Treynor index value of equity funds in 2010 to 2013 is smaller than this market can be traced through the Treynor index calculation formula, where the level of portfolio risk premium is divided by the systematic risk level or beta.

With the risk premium level of mutual funds being smaller than the market, it becomes one of the factors in the Treynor index value of mutual funds which smaller than the Treynor index value of the market. Coupled with the beta level or systematic risk of equity funds is greater than the market, making the value of Treynor obtained in mutual funds will be even smaller than the value of Treynor index in the market. By comparing the value of the Treynor Index on the return of mutual funds which are the object on this research with value of Treynor Index on return market it can be seen that the mutual funds which are these research object were outperform or underperform.

The Treynor Index calculation results show that 25 mutual funds have performance above the market or outperform in 2009, only 4 mutual funds in 2010, 11 mutual funds in 2011, 9 mutual funds in 2012, and 12 stock mutual funds in 2013. The ranking given based on the value of the Treynor Index which not much different from the results of the previous Sharpe Ratio calculation. The greater the value of the Treynor Index, the more it shows good performance on the portfolio. The Mandiri Investa UGM mutual fund was ranked first in 2009 with the highest Treynor Index value of 0.0689 . The first rank of the Treynor Index calculation is the same as the first rank of the Sharpe Ratio calculation in 2010 to 2013. In 2010 the first rank was still occupied by the Panin Dana Maksima Portfolio Fund with the highest Treynor Index value of 0.1847. In 2011 the first rank was still occupied by Emco Mantap mutual fund with the highest Treynor Index value of 0.0118. In 2012 the first rank was still occupied by Syailendra Equity Opportunity with the highest Treynor Index value of 0.0169 . Finally in 2013 the first rank was occupied by Millennium Danatama mutual fund with the highest Treynor Index value of 0.0302 .

\section{$>$ Jensen's Alpha}

Calculations by using Jensen Alpha method also show that the value of Jensen's Alpha mutual funds was negative in 2010, 2011 and 2012, but in 2009 and 2013 the value of Jensen's Alpha mutual funds was positive. The value of Jensen's Alpha mutual funds in 2010, 2011 and 2012 was negative because the level of portfolio risk premium was smaller than the level of market risk, which the result of multiplication of market risk premium and greater than portfolio risk premium, with beta portfolio whose value is greater than 1) By comparing the value of Jensen's Alpha on the return of mutual funds which is the object on this research with the value of Jensen's Alpha on return market, it can be seen that the mutual funds which the object of this research have outperform or underperform performance.

The results of Jensen's Alpha calculation compared to the market show that 25 mutual funds have performance above the market performance or outperform in 2009, only 4 mutual funds in 2010, 11 mutual funds in 2011, 9 mutual funds in 2012, and 12 stock mutual funds in 2013. The total performance outperformed from Jensen's Alpha calculation results is exactly the same as the Treynor Index calculation results.

In 2010 to 2013, the first ranking from Jensen's Alpha calculation was the same as the first ranking from the calculation of the Treynor Index and Sharpe Ratio, namely the Panin Dana Maksima, Emco Mantap, Syailendra Equity Opportunity and Millennium Danatama mutual fund. Only the first rank of Jensen's Alpha value in 2009 was different from Sharpe Ratio and Treynor Index values, which is Panin Dana Prima.

Panin Dana Prima mutual fund was ranked first in 2009 with the highest value of Jensen's Alpha which is 0.0145. In 2010, the first rank was still occupied by Panin Dana Maksima Portfolio mutual fund with the highest value of Jensen's Alpha, 0.0290. In 2011 the first rank was still occupied by Emco Mantap mutual fund with the highest Treynor Index value of 0.0173. In 2012 the first rank was still occupied by Syailendra Equity Opportunity with the highest Treynor Index value of 0.0109. Finally in 2013 the first ranking was occupied by Millennium Danatama Equity Fund with the highest Treynor Index value of 0.0441 . 
Comparison between Sharpe Ratio, Treynor Index and Jensen's Alpha

The calculation results of Sharpe Ratio, Treynor and Jensen methods for January 2009 to October 2013, shows that 2 mutual funds have performance above the market performance or outperform in the Sharpe Ratio (Panin Dana Maksima and Panin Dana Prima) only 5 mutual fund Shares the same in the Treynor Index method and Jensen's Alpha (Panin Dana Maksima Portfolio, Panin Dana Prima, Millennium Danatama Equity Fund, Corfina Capital Grow 2 Prosper and Emco Mantap).

From those above ranking there are 7 ranks that are consistently measured by the Sharpe Ratio, Treynor Index and Jensen's Alpha methods, namely the first rank of the Panin Dana Maksima Portfolio, the second Panin Dana Prima, the seven Trimegah Trim Kapital Plus, the nine BNP Paribas Solaris Fund, the thirty-one NISP Index Progressive Shares, thirty-two Mandiri Investa Atraktif and thirty-eight Batavia Agro Funds.

The results of calculations with the Sharpe Ratio and Treynor Index methods have 2 consistent rankings, namely the thirty-third ranking of Lautandhana Equity and the thirty-fifth of the Aggressive Danareksa Mawar mutual fund. More consistency in ranking is seen from the results of the calculation of the Treynor Index method and Jensen's Alpha, there are 10 consistent rankings, namely the third rank of the Millennium Danatama Equity Fund, the fourth Corfina Capital Grow 2 Prosper, the fifth Emco Mantap, the eighth Schroder Dana Istimewa, the twelfth Syailendra Equity Opportunity Fund, the thirteenth Batavia Dana saham optimal, the fourteenth BNP Paribas Pesona, the fifteenth Manulife Saham Andalan, the twentieth Batavia dana saham and the thirteen seventh BNI Berkembang.

In plain view, the consistency of the Sharpe Ratio, Treynor Index and Jensen's Alpha methods can be seen by ranking the results of calculations with the Sharpe Ratio, Treynor Index and Jensen's Alpha methods. From the test results, it can be seen that using the Sharpe Ratio, Treynor Index and Jensen's Alpha methods, the ranking obtained for each equity fund is not much different. This clearly shows that the results of the mutual funds Performance sizing methods by the Sharpe Ratio, Treynor Index and Jensen's Alpha methods have consistency. This consistency could also be tested by statistical methods.

\begin{tabular}{|c|c|c|c|c|}
\hline No & Stock Mutual Funds & Sharpe Ratio & Treynor Index & Jensen's Alpha \\
\hline 1 & Bahana TCW Dana Prima & 0,2141 & 0,0128 & $-0,0038$ \\
\hline 2 & Batavia Dana Saham & 0,2323 & 0,0141 & $-0,0025$ \\
\hline 3 & Batavia Dana Saham Agro & 0,0604 & 0,0041 & $-0,0148$ \\
\hline 4 & Batavia Dana Saham Optimal & 0,2523 & 0,0156 & $-0,0007$ \\
\hline 5 & BNI Berkembang & 0,1441 & 0,0098 & $-0,0081$ \\
\hline 6 & BNP Paribas Ekuitas & 0,242 & 0,0144 & $-0,002$ \\
\hline 7 & BNP Paribas Infrastruktur Plus & 0,2244 & 0,0134 & $-0,0032$ \\
\hline 8 & BNP Paribas Pesona & 0,2495 & 0,0148 & $-0,0015$ \\
\hline 9 & BNP Paribas Solaris Fund & 0,252 & 0,016 & $-0,0002$ \\
\hline 10 & CIMB-Principal Equity Aggressive & 0,164 & 0,0098 & $-0,0068$ \\
\hline 11 & Corfina Capital - Grow 2 Prosper & 0,2648 & 0,0173 & 0,0013 \\
\hline 12 & Dana Ekuitas Andalan & 0,214 & 0,0127 & $-0,0037$ \\
\hline 13 & Dana Ekuitas Prima & 0,2303 & 0,0138 & $-0,0027$ \\
\hline 14 & Danareksa Mawar & 0,2316 & 0,014 & $-0,0023$ \\
\hline 15 & First State IndoEquity Dividend Yield Fund & 0,2268 & 0,0135 & $-0,0026$ \\
\hline 16 & First State Indoequity Value Select Fund & 0,2262 & 0,0135 & $-0,0027$ \\
\hline 17 & GMT Dana Ekuitas & 0,2562 & 0,0158 & $-0,0004$ \\
\hline 18 & Lautandhana Equity & 0,1791 & 0,011 & $-0,0056$ \\
\hline 19 & Mandiri Investa Atraktif & 0,1919 & 0,0116 & $-0,0051$ \\
\hline 20 & Mandiri Investa UGM & 0,1314 & 0,0102 & $-0,0053$ \\
\hline 21 & Manulife Dana Saham & 0,2411 & 0,0144 & $-0,0018$ \\
\hline 22 & Manulife Saham Andalan & 0,2438 & 0,0146 & $-0,0018$ \\
\hline 23 & Millennium Danatama Equity Fund & 0,2205 & 0,0198 & 0,0034 \\
\hline 24 & NISP Indeks Saham Progres if & 0,2014 & 0,012 & $-0,0042$ \\
\hline 25 & Panin Dana Prima & 0,3347 & 0,0214 & 0,006 \\
\hline 26 & Portfolio Panin Dana Maksima & 0,3777 & 0,0237 & 0,0087 \\
\hline 27 & Pratama Ekuitas & 0,2202 & 0,0143 & $-0,0025$ \\
\hline 28 & Pratama Saham & 0,2453 & 0,0159 & $-0,0005$ \\
\hline 29 & Reks a Dana Danareksa Mawar Agresif & 0,1592 & 0,01 & $-0,0073$ \\
\hline 30 & Rencana Cerdas & 0,2155 & 0,013 & $-0,0034$ \\
\hline 31 & Schroder Dana Is timewa & 0,2651 & 0,016 & $-0,0002$ \\
\hline 32 & Schroder Dana Prestasi Plus & 0,2301 & 0,0137 & $-0,0025$ \\
\hline 33 & Syailendra Equity Opportunity Fund & 0,2485 & 0,0157 & $-0,0006$ \\
\hline 34 & Trimegah - Trim Kapital & 0,229 & 0,0141 & $-0,0025$ \\
\hline 35 & Trimegah - Trim Kapital Plus & 0,255 & 0,0161 & 0.0000 \\
\hline 36 & Emco Growth & 0,2128 & 0,0141 & $-0,0022$ \\
\hline 37 & Emco Mantap & 0,2376 & 0,0165 & 0,0005 \\
\hline \multicolumn{2}{|r|}{ Rata-rata Reksa Dana Saham } & 0,225 & 0,0141 & $-0,0023$ \\
\hline \multicolumn{2}{|r|}{ Market (IHSG) } & 0,2757 & 0,0162 & 0 \\
\hline
\end{tabular}

Table 3:- Comparison between Sharpe Ratio, Treynor Index and Jensen's Alpha Results 


\section{B. Examinations over the Consistency of Sizing Methods}

Analysis of the consistency results shows that in period January 2009 to October 2013 the value of W was 0.182 . The test results show that only the measurement method in period January 2009 to October 2013 was proved significant at a probability level of $5 \%$, this can be seen asympt.sig value $<0.05$. Thus, it could be Stated that there has consistency or harmony in evaluating the performance of mutual funds by using the Sharpe Ratio, Treynor Index and Jensen Alpha methods in period Of january 2009 to October 2013

\section{Test Statistics}

\begin{tabular}{|c|c|}
\hline & Value \\
\hline Kendall's W & a \\
\hline Asymp. Sig. & 0,182 \\
\hline
\end{tabular}

a. Kendall's Coefficient of Concordance

Table 4:- Kendall's W Test Statistical Results

Total risk consists of systematic and unsystematic risk. Systematic risk cannot be eliminated, while unsystematic risk can be minimized through efficient diversification, so the total remaining risk is systematic risk (Kaaro, 2007). Thus mutual fund risk has been managed efficiently when total risk is the same as systematic risk, because unique risks are well diversified.

A consistent sequence of mutual fund performance shows that mutual fund risk management has been carried out efficiently. Treynor Index emphasizes systematic risk, Sharpe Ratio emphasizes total risk. If the performance sequence is inconsistent, it means that mutual fund management has not been able to eliminate the unique risks of the portfolio formed.

\section{Discussion}

The performance evaluation study result has shown that mutual funds view through Sharpe Ratio, Treynor and Jensen calculation methods during the surveillance period and It appears that there are two mutual funds that exceel above market or outperform according to Sharpe Ratio (Panin Dana Maksima and Panin Dana Prima Portfolios) and there was only 5 shares are the same for Treynor Index and Jensen Alpha (Panin Dana Maksima Portfolio, Panin Dana Prima, Millennium Danatama Equity Fund, Corfina Capital Grow 2 Prosper and Emco Mantap).

The consistency Analysist test results was Described during Research period that the value of $\mathrm{W}$ was 0.182 . The test results was indicated that the sizing method during the observation period has Authentic significant value at the $5 \%$ probability level, seen asympt.sig value $<0.05$. Therefore It said that there has consistency Occurs or harmonized in this periods assessed from Sharpe Ratio, Treynor Index and Jensen's Alpha.

\section{CONCLUSIONS AND SUGGESTIONS}

A. Conclusion

The conclusions that the authors could drawn based on the research results above as follows:

> Panin Dana Maksima and Panin Dana Prima Portfolio are the best stock mutual funds because they are consistently appeared in every list of high levels stock mutual funds above the market, such as computing using average returns, Sharpe Ratio method, Treynor Index and Jensen's Alpha during the period of January 2009 to October 2013.

$>$ The performance assesment result when viewed based on the average returns of 37 sample stock mutual fund during the period January 2009 to October 2013 and obtained an average value of stock mutual fund returns lower than the average market return only 17 stock mutual funds that exceeded market performance and 20 other mutual funds below market performance. Then it was indicated that performance was efficient during this period

$>$ From performance sizing result in 2009, the Sharpe Ratio method ranked first was Panin Dana Maksima , Treynor Index method ranked first was Mandiri Investa UGM and Jensen Alpha's first ranking was Panin Dana Prima. Furthermore, in 2010, 2011, 2012 and 2013 the first ranking of Sharpe Ratio, Treynor Index and Jensen's Alpha performance sizing methods is consistent like such as in 2010 Panin Dana Maksima Portfolio, in 2011 Emco Mantap mutual fund, 2012 Syailendra Equity Opportunity Fund and 2013 Panin dana maksima. The sizing results of sharpe Ratio, Treynor Index and Jensen Alpha method during the period January 2009 to October 2013, the first and second ranks are consistently occupied by Panin Dana Maksima and Panin Dana Prima.

$>$ The consistency test result over mutual funds performance during period of January 2009 to October 2013 by Kendall W concordance coefficient, has earned that $\mathrm{W}$ value is 0.182 and Authenticated significant at $5 \%$ probability level. Therefore it stated that there has occur the consistency or harmony in evaluating mutual funds performance by using Sharpe Ratio, Treynor Index and Jensen Alpha methods in period of January 2009 to October 2013.

\section{B. Suggestion}

Based on these research results, the author tries to offered several suggestions, such as:

$>$ For investors, the Panin Dana Maksima and Panin Dana Prima could be used as an choice to invest in portfolio programme. The two mutual funds are continually made it in every list of mutual funds with good performance levels above the market, both estimate average returns or by using Sharpe Ratio, Treynor Index, and Jensen Alpha methods during period of January 2009 to October 2013. 
Performance calculations using the Sharpe Ratio, Treynor Index, and Jensen's Alpha methods during the period of January 2009 to October 2013 were also according to the previous research. The results obtained could be taken into recommendation for investors to evaluating the performance of stock mutual fund when making investment decisions in the future. nevertheless this results cannot be used as a source of information it is because the level of performance wont be similiar in the future. Various aspects will affect the performance of those indexs in the future. So analyzes are needed before making investment decisions.

\section{REFERENCES}

[1]. Husnan, Suad. (2001). Dasar-dasar Teori Portofolio dan Analisis Sekuritas, edisi ketiga, Yogyakarta: UPP AMP YKPN.

[2]. Republik Indonesia. (1995). Undang-Undang (UU) Nomor 8 Tahun 1995 tentang Pasar Modal

[3]. Usman, Bahtiar dan Indri Ratnasari. 2004. "Evaluasi Kinerja Reksa Dana Berdasarkan Metode Sharpe, Treynor, Jensen dan M2 ." Media Riset Bisnis dan Manajemen, Vol. 4 No. 2, Hal 165-202.

[4]. http://aria.bapepam.go.id.

[5]. www.bi.go.id

[6]. www.yahoofinance.com. 